


\section{A More}

Comprehensive Forest Policy For Minnesota

$$
\text { By Wm. T. Cox }
$$

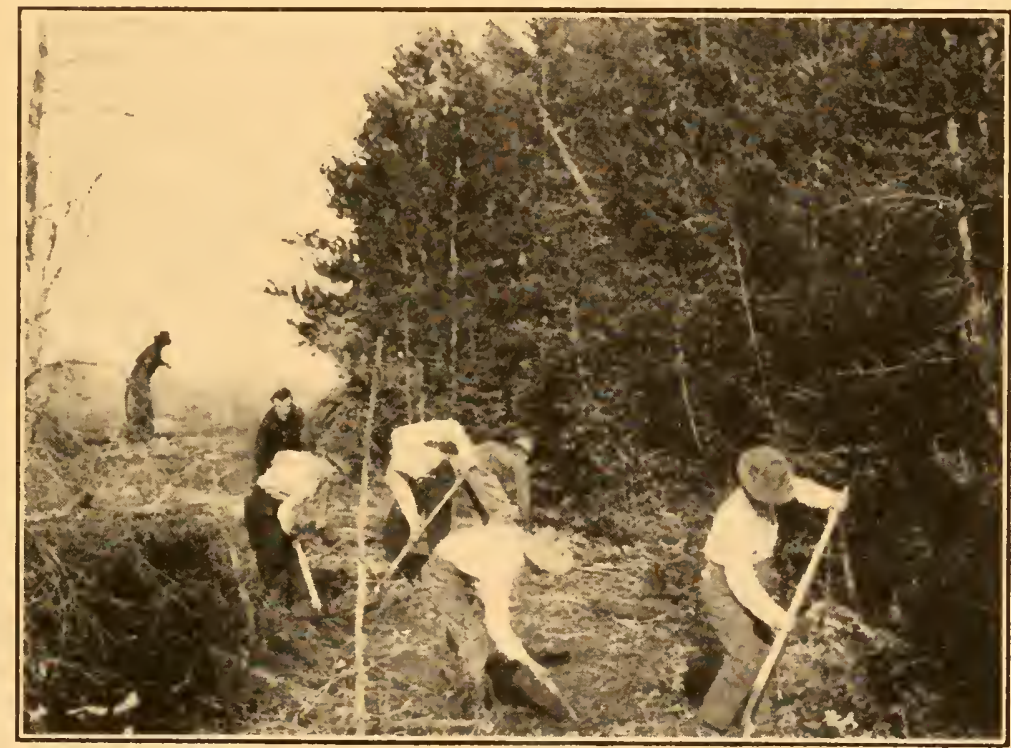

Fire Fighting $C_{\text {rew }}$ Trenching ahead of a Fire

In a similar way hundreds of forest fires are put out every year ;

MINNESOTA FOREST SERVICE 
D. of D.

OCT $30 \quad 1919$

$\therefore \vdots$ 


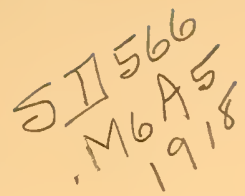

\section{A More Comprehensive Forest Policy For Minnesota}

Wm. T. Cox

Minnesota needs a more definite forest policy. The lives of our citizens are in need of better protection. Our native forests cry out for the opportunity to exist and produce, to protect and beautify. Our waste lands eall for planting and our prairies for the shelter of trees.

One-half the area of Minnesota is devoted to tree growth, and forestry ranks second among the great industries of the state. Besides the lumber, the pulpwood, the millions of ties and other timber products produced our forests make usable the great watew powers and the navigable streams. They make liveable our lakes for niyriads of fish, they afford a home for game and fur bearing animals which otherwise must perish. They give the touch of beauty to our hills and lakes which in the near future means a million tourists a year.

We have abused our forests while other countries were building up theirs. We are cutting our timber far faster than it is being produced, and yet there is an inereasing need for timber products. It is time to wake up before we are dependent on other countries.

The well managed forests of France and Belgium saved those countries and civilization from the onslaught of the Hun. Ask any man who fought on that awful western front during 1916, 1917 and 1918.

One of our fundamental difficulties is a wrong system of taxation. This needs revision. Put a nominal tax on the land devoted to tree growth, then tax the timber when cut. This will give some incentive for taking care of such property. Young or half grown timber is not valued by owners now.

Patrol by rangers is the approved method used in all countries where forests are given real protection. Other measures are helpful, but without systematic patrol of the wools-at least one man to every four to six townships, all other measures are of little use in reducing the danger of forest fires. Hundreds of forest fires were put out last year by the rangers or through their efforts. How many more were prevented nobody knows.

We have asked each session since 1911 for means to provide a woodsman to patrol each six townships in the coniferous forest region. This man to work for the state and see that the townships, the railroads and the 
timber operators to their part, which is a much larger one. \$150,000 a year was asked until last year, when owing to higher wages and greater clanger resulting from ditching and increased settlement, $\$ 330,000$ was asked. It is not our place to say how this sum be raised, but we dlo know that it is neefled to protect from forest fires more than 250,000 people and a billion dollars worth of property. Different countries and states raise money in different ways for fire prevention. Some states assume the entire burden, others tax the land a cent or so an acre in the districts directly benefited; still others lax the timber output to raise a protection fund.

Minnesota has been bearing a part of the cost of patrol, the railroads, the townships and the timber operators have borme another part, and the timber operators have in addition borne the cost of slash flisposal, which owing to shortage of men to enforce orlers, has not always been well done.

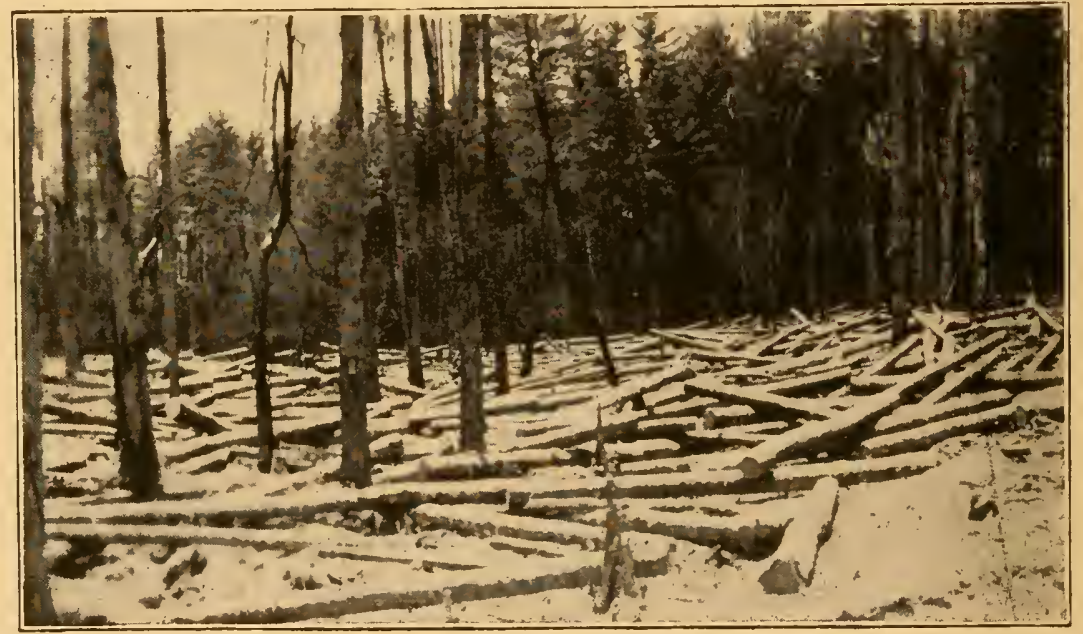

Pine timber cut under forestry rules-young trees left for further growth: slash all burned

The legislature, if it would provide adeduately against the occurrence of forest fires and preserve our forests and increase their productiveness in the future, might then consicler the following measmes:

1. Tax land separately from growing timber and tax the timber when cut.

2. Provite money enongh in some way to enable the Forest Service to have one man patroling, during the dry season from April to November. for every four townships of wooted country, and enough superior oflicers for efficient supervision,-haif the field force to be retained through the winter to enforce slash clisposal and supervise work on state forests. There are two thousand logging camps where slash disposal needs enforcement in atclition to thousands of settlers making small clearings. Raise maximum for permanent central organization, needed for supervision in proportion 
to increase in field expenditure. The present low maximum for this purpose is a serious handicap to obtaining greatest ellieiency of the field foree.

3. Appropriate $\$ 30,000$ for the construetion of telephone lines where most needed for fire protection.

4. Appropriate $\$ 100,000$ for elearing up areas of very dangerous blowdowns, crews to work mnder the direction of experienced rangers. Otherwise more harm than good might follow.

5. Grant greater authority to Forester with regard to railroad fire prevention, e. g., putting out of service engines which are particularly dangerous.

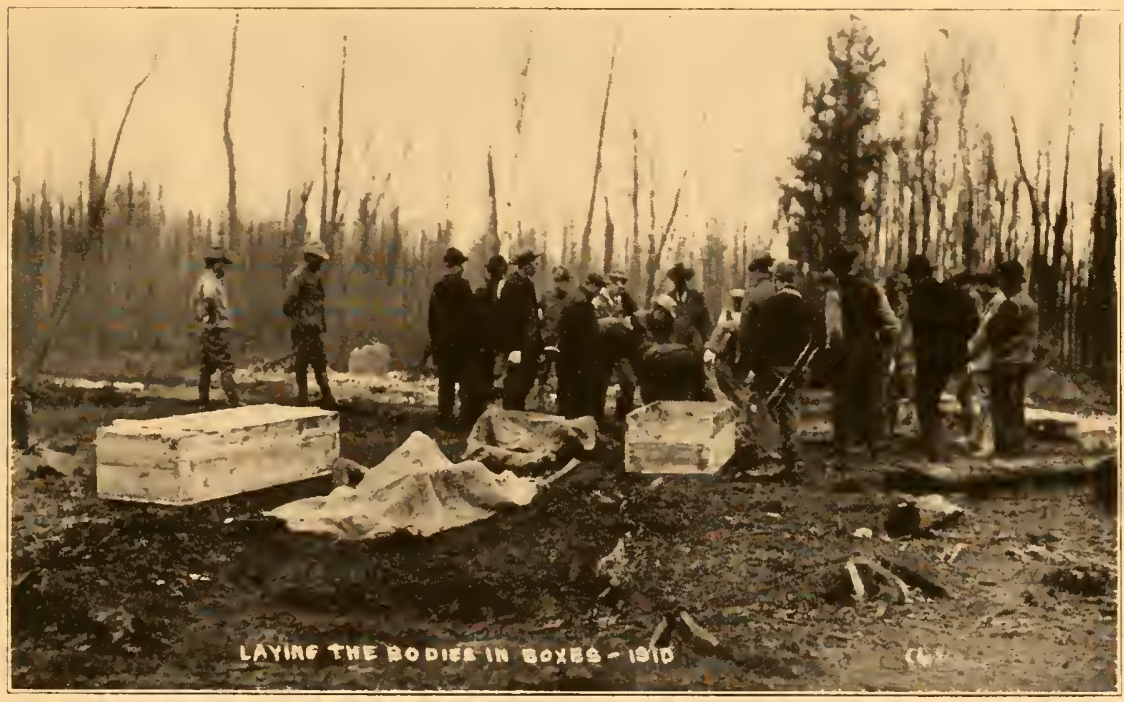

A scene repeated many times in the fires of October, 1918

6. Encourage by some kind of legislation the grazing of live stock in the wooded portions of the state. Sheep in particular render the woods eomparatively safe from lire, and are a great aid to fire control.

7. Reserve all areas of state owned pulpwood timber and areas of half grown pine and other timber of eommereial varieties, irrespective of what kind of soil it may be on. Reserve also all state owned land that will bring better returns in forest than in poor pasture and farms. Plant to spruce and pine portions of such lands now barren.

8. Purchase at reasonable prices private lands now bearing natural stands of promising young timber. The state will profit greatly by holding and protecting it the comparatively short time it will take to mature. 
9. Purchase at a nominal price all $3 \mathrm{r}$ ( 1 and 4 th class land whether bearing young trees or not. Plant if necessary.

Or, if a delinquent tax law can be framed that will really work in this state, obtain such lands by that means. It has been the practice to pass acts from time to time permitting payment of back taxes at fifty cents on the dollar, thus putting a premium on delinquency and never getting title to the land so it could be put to useful purpose. It may be necessary to tax mineral rights separately from surface rights to have a workable delinguent tax.

10. Make provision for the practice of forestry on all lands reserved or bought for state forests. This will help to make permanent settlements which otherwise must be temporary and continue an industry whiclı means much to the prosperity of agriculture and manufacturing throughout the state.

11. Make inducements for the retention or planting of woodlots and their proper care on farms. Such tracts to contain a good percentage of the more valuable kinds of trees. Encourage by practical means the saving or planting of shelterbelts around fields to protect against drying winds and the spread of noxious weeds.

12. Encourage the establishment of the smaller wood using industries so that logging and land clearing where done will not be so expensive or so wasteful of timber products.

13. Provide for the construction of a road from Crane Lake through Ely to Lake Superior, the state to pay half the cost and the U. S. Government the other half. Such road is badly needled as a lire protective measure.

14. Memorialize Congress to increase the cooperative fire protection fund from $\$ 100,000$ to $\$ 600,000$ so that Minnesota will get about $\$ 50,000$ a year under the "Weeks Law," instead of $\$ 8,000$.

15. Memorialize Congress and the Navy Department to establish a training station at Duluth where men may be trained in the use of hydroaeroplanes and, as part of their training, patrol the northeastern portion of this state to locate fires which may be burning in the woods and lake country.

16. Provide a closed season on burning except under permit from an authorized officer.

17. Provide a building at the State Fair Grounds to exhibit forestry work, including forest products and logging and wood-working machinery. 



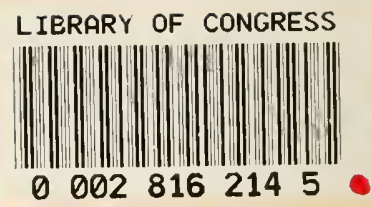



LIBRARY OF CONGRESS

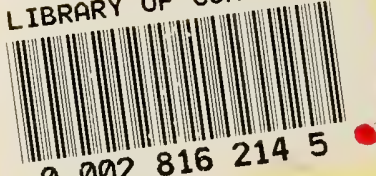

00028162145 